\title{
Psychological Impacts and Attitudes of the Syrian Population Regarding the COVID-19 Pandemic and Face Masks During the First Syrian Lockdown
}

Fatema Mohsen ( $\square$ fatemamohsena@gmail.com)

Syrian Private University Faculty of Medicine https://orcid.org/0000-0003-3472-6099

Batoul Bakkar

Syrian Private University Faculty of Medicine

Judy Kikhia

Syrian Private University Faculty of Medicine

Dana Mchantaf

Syrian Private University Faculty of Medicine

Samar Aldakkak

Syrian Private University Faculty of Medicine

Alma Najjar

Syrian Private University Faculty of Medicine

Marah Marrawi

Syrian Private University

Youssef Latifeh

Syrian Private University Faculty of Medicine

Research

Keywords: Attitude, Syria, Masks, War, COVID-19.

Posted Date: June 3rd, 2021

DOI: https://doi.org/10.21203/rs.3.rs-528706/v1

License: @ (i) This work is licensed under a Creative Commons Attribution 4.0 International License. Read Full License 


\section{Abstract \\ Background}

This study assesses the attitudes and psychological impacts regarding COVID-19 and face masks among the Syrian population during the current pandemic and war.

\section{Methods}

A web-based cross-sectional Arabic survey design was employed. The survey was distributed in May 2020 during the COVID-19 pandemic and civil war in Syria. The survey contained items relating to socio-demographic characteristics and items assessing attitudes regarding COVID-19, and face masks. The chisquare test was applied to the questions against socio-demographic variables.

\section{Results}

Of the 4148 participants, 3053(73.6\%) were female, and 3238(78.1\%) were single. 423(10.2\%) and 1573(37.9\%) stated they had poor and moderate economic status respectively. Home quarantine has led to an increase in family problems 3016(72.7\%) and has had a negative psychological impact upon $1666(40.2 \%)$ Syrians. $538(13.0 \%)$ are shy about wearing face masks in public.

\section{Conclusion}

Mountainous input from the Syrian government is needed to combat the threat of COVID-19 through targeted awareness campaigns and national helplines aimed at specific socio-demographic variables.

\section{Introduction}

Coronavirus disease 2019 (COVID-19) is a highly infectious respiratory disease that evolved into a worldwide pandemic, spreading through respiratory aerosols invading all mucous membranes in contact. The virus continues to spread worldwide, burdened with the effects of morbidity and mortality, hitting the poorest and most vulnerable in the world. Live statistics are tracking the number of confirmed cases, recovered patients, and death toll daily.(1) Syria announced its first confirmed case on 22 March 2020, with numbers steeply rising since then.(2) The battle against COVID-19 has just entered its third wave in Syria. $(3,4)$

The COVID-19 pandemic forced governments worldwide to impose draconian lockdowns and coerce their citizens to abide by strict preventive health practices to reduce infection rates. The use of face masks alone in the control and prevention of COVID-19 remains an issue of debate. $(5,6)$ At the start of the pandemic, the World Health Organization (WHO) recommended that face masks not be worn by the public and that masks should be reserved for healthcare workers and symptomatic individuals. $(7,8)$ WHO also stated that masks provided a false sense of security and that the use of face masks would cause people to touch their faces, thereby increasing their chances of contracting COVID-19 infection, rendering face masks ineffective for public use.(7, 9) Evidence supporting the use of face masks steadily emerged. $(10,11)$ Health authorities such as WHO subsequently reversed their opposition on face masks and urged governments to encourage the use of facemasks among the public where social distancing measures cannot be established.(12)

After 10 years of conflict, life is harder than ever for displaced Syrians. 13.4 million Syrians have been forced to flee their homes since 2011, seeking safety as refugees in Lebanon, Turkey, Jordan, and beyond, or displaced inside Syria.(13) The 6.7 million internally displaced Syrians are overcrowding many governorates. (13) Due to the dense population, social distancing cannot be ensured; therefore, face mask use must be promoted in the country. The demand for face masks has grown since the start of the pandemic in Syria. Amid the high prices of the imported face masks, the Syrian Education Ministry, vocational institutes started producing masks as the education in these facilities had been suspended as part of the government's measures to curb the spread of COVID19.(14) An average of 3,000 facemasks is produced per day. (14)

It has become increasingly apparent that behavioral science is vital for optimal pandemic management, and understanding and addressing pandemic related socially disruptive phenomena including the reluctance or refusal to follow health measures such as the wearing of face masks. $(15,16) \mathrm{A}$ few studies have addressed attitudes regarding face masks during the COVID-19 pandemic;(17-19) however, none have assessed the attitudes of wearing face masks among the Syrian population during the pandemic embedded within the war.

This study aims to assess attitudes and psychological impacts regarding COVID-19 and face masks during the current pandemic and Syrian conflict. The objectives are to identify correlations between the attitudes and socio-demographic characteristics of participants.

\section{Methods}

\section{Study design, setting, and participants:}

This web-based cross-sectional study was conducted using an Arabic questionnaire during May of 2020. The sample size calculated was 2401 participants based on a margin of error of $2 \%$, and a confidence interval of $95 \%$, for a population of $17,500,657$ people using a sample size calculator (website: https://www.surveysystem.com/sscalc.htm).(20) All participants residing in Syria, who fully completed the survey, and who can read and understand Arabic 
were included in the study. Participants under the age of 18 (years) required informed parental consent and were instructed to supply parent/guardian contact information. The researchers were responsible for contacting the parents/guardians to obtain consent before granting the child access to complete the questionnaire. The authors designed questions modelled after existing surveys to assess attitudes and psychological impacts regarding COVID-19 and face masks.(21) The survey was translated into Arabic and was reviewed by two dialectologists and two psychiatrists, who evaluated whether the questions effectively assessed attitudes regarding both COVID-19 and face masks, and checked for double-barreled and confusing questions. A pilot study was conducted on 20 individuals to assess the relevance, clarity, and acceptability of the questionnaire. These were excluded from the final sample to avoid bias. Modifications were made based on feedback received to facilitate better comprehension before distributing the final questionnaire to the general population. The questionnaire was distributed through various social media platforms including WhatsApp, Telegram, and Facebook. After providing informed consent online, participants were directed to the first part of the survey to complete 9 questions about socio-demographic information including gender, age, residence, education level, occupation, marital status, number of household members, and economic status. Participants were also asked about the history of chronic diseases. The second part of the questionnaire contained 12 questions divided into two sections: COVID-19 (7 questions), face masks (5 questions). Ethical approval was obtained from the Institutional Review Board (IRB) of the Faculty of Medicine, Syrian Private University. Both the Arabic and English versions of the questionnaire are provided in appendix 1.

\section{Statistical analysis:}

Frequencies and percentages (for categorical variables) or means and standard deviations (SD) (for continuous variables) were reported. The chi-square test was applied to compare the 12 questions against socio-demographic variables (gender, age, residence, education level, occupation, marital status, number of household members, and economic status). All p-values $<0.05$ were considered statistically significant.

\section{Results}

\section{Socio-demographics characteristics:}

Of the 5000 total participants who participated in the study, a final sample size of 4148 participants met inclusion criteria (completion rate $=83.0 \%$ ), $3053(73.6 \%)$ of whom are female, and $1095(26.4 \%)$ of whom are male. The majority were single $3238(78.1 \%)$ and had attained college/university level degree $3278(79.0 \%)$. Participants' ages ranged from 12 to 70 years, with the age group 18-25 years representing a majority $2870(69.2 \%)$, while the age group $>64$ years representing a minority $6(0.1 \%)$. A total of $423(10.2 \%)$ and $1573(37.9 \%)$ participants stated they had poor and moderate economic status respectively. $580(14.0 \%)$ participants mentioned a history of chronic disease(s) such as diabetes mellitus, hypertension, cardiac conditions, respiratory conditions, and others (Table 1).

\section{Attitudes and impact of COVID-19 pandemic:}

Responses varied regarding the successful control of COVID-19, 2274(54.8) agreed, 1404(33.8) did not know, and 470(11.3) disagreed. Only 2605(62.8\%) participants are abiding by home quarantine rules. A minority of 388(9.4\%) participants are finding themselves unprepared to face the national spread of the COVID-19 pandemic. Home quarantine has led to an increase in family problems 3016(72.7\%), negative psychological impact 1666(40.2\%), and feeling lazy and inactive $3470(83.7 \%$ ) among participants (Table 2).

\section{Attitudes and impact of face masks:}

The majority of participants support the use of face masks in public $2943(70.9 \%)$. Shockingly, 538(13.0\%) are shy about wearing a face mask in public, whereas 335(8.1\%) do not know. The majority of participants reported having no inferior view of those who wear a face mask, not worrying about what people would say about them if they wear face masks, and will not cease the use of face masks if embarrassed or bullied by any individual, representing 4010(96.7\%), 3288(79.3\%), and 3237(78.0\%) respectively (Table 2).

\section{Attitudes and psychological impact towards COVID-19 by socio-demographic variables:}

Attitudes towards successful control of COVID-19 significantly differed across gender $(p<0.001)$, age group ( $p=0.001)$, social status ( $<<0.001)$, education level $(\mathrm{p}<0.001)$, and occupation $(\mathrm{p}<0.001)$ (Table 3$)$.

The thought of self or family contracting COVID-19 infection significantly differed across gender $(p<0.001)$, age group ( $p=0.027)$, social status ( $<<0.001)$, education level $(p=0.012)$, occupation $(<0.001)$, economic status $(p=0.012)$, and chronic disease $(s)(p=0.002)($ Table 3$)$.

Preparedness to face the national spread of pandemic significantly differed across gender $(p=0.007)$, age group $(p=0.001)$, social status $(p<0.001)$, education level $(p=0.026)$, occupation $(<0.001)$, and economic status $(p<0.001)$ (Table 4$)$.

Abiding to home quarantine rules significantly differed across gender $(p<0.001)$, age group $(p<0.001)$, social status $(p<0.001)$, area $(p=0.015)$, education level $(p<0.001)$, occupation $(p<0.001)$, and economical status $(p<0.001)$ (Table 4$)$.

Home quarantine leading to an increase in family problems significantly differed across gender $(p<0.001)$, age group $(p<0.001)$, social status ( $<<0.001)$, education level $(p=0.002)$, occupation $(p<0.001)$, economic status $(p=<0.001)$, and chronic diseases $(s)(p=0.001)($ Table 5$)$.

Home quarantine having a positive impact on psychological state significantly differed across gender $(p<0.001)$, age group ( $<<0.001)$, social status $(p<0.001)$, education level $(p=0.025)$, occupation $(p<0.001)$, economical status $(p<0.001)$, and chronic diseases $(s)(p=0.007)($ Table 5$)$. 
Home quarantine leading to laziness and inactiveness significantly correlated with gender $(p=0.003)$, age group $(p<0.001)$, social status $(p<0.001)$, education level $(p<0.001)$, and occupation $(p<0.001)$ (Table 6).

\section{Attitudes and psychological impact towards face masks by socio-demographic variables:}

Attitudes towards supporting wearing face masks significantly differed across gender $(p<0.001)$, age group $(p<0.001)$, social status $(p<0.001)$, occupation $(p<0.001)$, and economical status $(p=0.034)$ (Table 6).

Being shy with regards to wearing face masks in public significantly differed across gender $(p<0.001)$, age group $(p=0.020)$, social status $(p=0.020)$, occupation ( $p<0.001)$, and economical status $(p=0.046)$ (Table 7).

Having an inferior view of those who wear a face mask significantly differed across gender $(p<0.001)$, age group $(p<0.001)$, and education level $(p<0.001)$ (Table 7).

Worrying about what people would say about you if you wear a face mask significantly differed across age group $(p<0.001)$, social status $(p<0.001)$, education level ( $p=0.013)$, and occupation $(p<0.001)$ (Table 8).

Ceasing the use of face masks if embarrassed or bullied by others significantly differed across gender $(p=0.007)$, age group ( $<<0.001)$, social status ( $<<0.001)$, occupation ( $p=0.003)$, and economical status $(p=0.008)$ (Table 8$)$.

\section{Discussion}

To the best of our knowledge, this is a first report assessing Syrians Attitudes and psychological impacts regarding both COVID-19, and face masks during the current pandemic.

Our results showed that approximately half of the participants believed that the pandemic will be finally controlled. This finding is lower compared with studies conducted in China and Malaysia. $(21,22)$ This attitude could be attributed to the severely under-equipped Syrian healthcare system that lacks the capacity to contain such a pandemic. The estimated number of intensive care unit beds with ventilators is a mere 325 , and the theoretical maximum number of cases that can be adequately treated is only 6,500.(23) In the absence of a vaccine, effective treatment protocol for COVID-19 and medications at the time of the survey, the hope of such a crisis to be tamed has diminished.

The majority of participants supported wearing face masks publicly. Since the outbreak of COVID-19, the importance of using face masks has become ubiquitous. Previous studies conducted at the same institution reported a high level of awareness, $89.3 \%$ knew that wearing a face mask outside was a preventive measure against the spread of COVID-19; however, only $39.1 \%$ of the Syrian population wore face masks publicly.(24, 25) Face masks can break the transmission cycle of respiratory microorganisms.(5) However, effectiveness can be limited by the lack of any of the following 3 : knowledge, practice, and attitude.

Almost all participants did not have an inferior view of those who wear a face mask. Despite that, a small proportion of participants stated they will stop wearing face masks if they are embarrassed or bullied by individuals. This result reflects the lack of national bullying helplines and organizations to support victims in Syria.

The quarantine negatively affected participants' psychological state, with the majority suffering from an increase in family problems, and feeling lazy and inactive. This is not surprising as the majority of them were abiding by home quarantine rules. A study conducted during the COVID-19 pandemic revealed that most Syrians suffer from depressive (83.4\%) and anxiety (69.6\%) symptoms.

This novel pandemic parallels a deteriorating Syrian economy and has increased demand for many products including face masks resulting in a supply shortage- driving the nation into a hyperinflation crisis.(26) Millions of Syrians are in poverty, forced to choose between buying food to escape starvation and face masks to escape morbidity and mortality.(27)

\section{Strengths and limitations:}

A major strength of this study lies in its large sample recruited during a critical period, the early stage of the COVID-19 pandemic and the civil war. On the other hand, this study has several limitations. First, due to the over-representation of the well-educated Syrians of good socio-economic status, in the sample, the findings may not generalize to other groups of the Syrian population especially those who lack access to the internet. Elderly and rural residents that have limited access to the internet represented a minority in this study. Second, self-reporting has certain limitations compared with structured interviews. Third, Credible published national data regarding the socio-demographic characteristics of Syrians are not available to evaluate the representativeness of our sample.

\section{Conclusion}

This study has revealed varying attitudes and significant psychological impacts regarding both the COVID-19 pandemic and face masks. Based on the findings the Syrian government must put efforts into providing national helplines for Syrians and reach out to targeted groups to provide further support.

\section{Abbreviations}




\section{Declarations}

\section{Ethics approval and consent to participate:}

This study was approved by the Institutional Review Board (IRB) at the Syrian Private University (SPU); however, we were not given a reference number. Informed consent was obtained from all participants. Participants under the age of 18 required verbal informed parental consent, as well as submission of parent/guardian contact information. The researchers were responsible for contacting the parents/guardians to obtain verbal consent before the child was given access to the survey. The verbal and written form of consent was approved by the IRB at SPU. Participation in the study was voluntary and participants were assured that anyone who was not inclined to participate or decided to withdraw after giving consent would not be victimized. All information collected from this study was kept strictly confidential. All methods were carried out following relevant guidelines and regulations.

\section{Consent for publication:}

Not applicable.

\section{Availability of Date and material:}

All data generated or analysed during this study are included in this published article and its supplementary information files.

\section{Competing interests:}

The authors declare that they have no competing interests.

\section{Funding:}

This research did not receive any specific grant from funding agencies in the public, commercial, or not-for-profit sectors.

\section{Authors' contributions:}

BB conceptualized the study, participated in the design, wrote the study protocol, performed the statistical analysis, did a literature search, and drafted the manuscript. FM participated in study design, did a literature search, and drafted the manuscript. DM, SA, and AN conceptualized the study and participated in the design. MM participated in statistical analysis. JK and YL did a literature search and revision of the draft. All authors read and approved the final draft.

\section{Acknowledgments:}

We are thankful to the management of the Syrian Private University for the support in the field of medical training and research. We are thankful to everyone who participated in this study.

\section{References}

1. Woldometer. Coronavirus Update (Live).

2. McKernan B. Syria confirms first Covid-19 case amid fears of catastrophic spread. The Guardian. 2020.

3. Affairs UOftCoH, Organization WH. Syrian Arab Republic: COVID-19 Humanitarian Update No. 23 As of 1 February 2021. World Health Organization. 2021.

4. Al-awsat A. Syria Grapples with Third COVID-19 Wave. Alsharq Al-awsat. 2021.

5. Control. ECfDPa. Using face masks in the community: first update. 15 February 2021. ECDC: Stockholm. 2021.

6. Organization WH. Coronavirus disease (COVID-19) advice for the public: When and how to use masks. World Health Organization. 2020.

7. Feng S, Shen C, Xia N, Song W, Fan M, Cowling BJJTLRM. Rational use of face masks in the COVID-19 pandemic. 2020;8(5):434-6.

8. In April, Half of the Public Had Worn a Face Mask in the Past Month. Now, That Number Is 95\%. Morning Consult. 2020.

9. Mantzari E, Rubin GJ, Marteau TMJb. Is risk compensation threatening public health in the covid-19 pandemic? 2020;370.

10. Control CfD, Prevention. Considerations for wearing masks. 2020.

11. Chu DK, AkI EA, Duda S, Solo K, Yaacoub S, Schünemann HJ, et al. Physical distancing, face masks, and eye protection to prevent person-to-person transmission of SARS-CoV-2 and COVID-19: a systematic review and meta-analysis. 2020;395(10242):1973-87.

12. Mask use in the context of COVID-19. World Health Organization. 2020.

13. Refugees UNHCf. Syria emergency. 2021 15/03/2021.

14. huaxia. Syrian vocational institutes make masks amid COVID-19 infections. Xinhua. 2020.

15. Van Bavel J, Boggio P, Capraro V, Cichocka A, Cikara M, Crockett MJNHB. \& Ellemers, N.(2020). Using social and behavioural science to support CoVID-19 pandemic response.

16. Van Bavel JJ, Baicker K, Boggio PS, Capraro V, Cichocka A, Cikara M, et al. Using social and behavioural science to support COVID-19 pandemic response. 2020;4(5):460-71. 
17. Izhar R, Husain S, Tahir MA, Husain S, Hussain SJAPJoPH. Knowledge, Attitudes, and Practices of the Pakistani Population Regarding Facemasks During the COVID-19 Pandemic. 2021:1010539521997261.

18. Taylor S, Asmundson GJJPo. Negative attitudes about facemasks during the COVID-19 pandemic: The dual importance of perceived ineffectiveness and psychological reactance. 2021;16(2):e0246317.

19. Matusiak Ł, Szepietowska M, Krajewski P, Białynicki-Birula R, Szepietowski JJAic, University emooWM. Face masks use during the COVID-19 pandemic: Differences in attitudes and practices between medical and non-medical students. A survey of 2256 students in Poland. 2020.

20. Syrian Arab Republic Fact Sheet Globocan 2020. 2021.

21. Zhong B-L, Luo W, Li H-M, Zhang Q-Q, Liu X-G, Li W-T, et al. Knowledge, attitudes, and practices towards COVID-19 among Chinese residents during the rapid rise period of the COVID-19 outbreak: a quick online cross-sectional survey. 2020;16(10):1745.

22. Mohamad EM, Azlan AA, Hamzah MR, Tham JS, Ayub SHJm. Public knowledge, attitudes and practices towards COVID-19: A cross-sectional study in Malaysia. 2020.

23. Gharibah M, Mehchy Z. COVID-19 pandemic: Syria's response and healthcare capacity. 2020.

24. Mohsen F, Bakkar B, Armashi H, Aldaher N. A Crisis within a Crisis: COVID-19 Knowledge and Awareness among the Syrian Population-A National Survey Assessment. 2020.

25. Bakkar B, Mohsen F, Armashi H, Marrawi M, Aldaher N. A Crisis within a Crisis: An Assessment of COVID-19 Attitude and Practice among Syrians-A Crosssectional Study. 2021.

26. Office for the Coordination of Humanitarian Affairs, Organization WH. Syrian Arab Republic: COVID-19 Update No. 08 - 2 May 2020. 2020.

27. Cockburn P. 'A choice between bread and masks': Syrians face calamity as Trump's new sanctions combine with surging coronavirus. Independent. 2020.

\section{Tables}

Table 1

Socio-demographic characteristics of participants: $(n=4148)$

\begin{tabular}{|c|c|c|c|c|c|}
\hline \multirow[t]{2}{*}{ Gender(\%) } & Male & $1095(26.4)$ & \multirow[t]{6}{*}{ Education(\%) } & Primary School & $29(0.7)$ \\
\hline & Female & $3053(73.6)$ & & Intermediate School & 163(3.9) \\
\hline \multirow[t]{7}{*}{ Age(\%) } & $12-17$ & 159(3.8) & & Secondary school & $466(11.2)$ \\
\hline & $18-25$ & $2870(69.2)$ & & College/University & $3278(79.0)$ \\
\hline & $26-34$ & $685(16.5)$ & & Master's degree & $185(4.5)$ \\
\hline & $35-44$ & $261(6.3)$ & & $\mathrm{PhD}$ & $27(0.7)$ \\
\hline & $45-54$ & $121(2.9)$ & \multirow[t]{7}{*}{ Occupation(\%) } & Healthcare worker & $262(6.3)$ \\
\hline & $55-64$ & $46(1.1)$ & & Government institution & $239(5.8)$ \\
\hline & $>64$ & $6(0.1)$ & & Private institution & 202(4.9) \\
\hline \multirow[t]{3}{*}{ Marital Status(\%) } & Single & $3238(78.1)$ & & Business & $203(4.9)$ \\
\hline & Married & $715(17.2)$ & & Military & $35(0.8)$ \\
\hline & Other & $1959(4.7)$ & & Student & $2540(61.2)$ \\
\hline \multirow[t]{4}{*}{ Economic Status(\%) } & ${ }^{4}$ Excellent & $267(6.4)$ & & Other & $667(16.1)$ \\
\hline & ${ }^{3}$ Good & $1885(45.4)$ & \multirow[t]{3}{*}{ Household members(\%) } & Alone & $54(1.3)$ \\
\hline & ${ }^{2}$ Moderate & 1573(37.9) & & $1-5$ & $2573(62.1)$ \\
\hline & ${ }^{1}$ Poor & $423(10.2)$ & & $>5$ & $1521(36.7)$ \\
\hline \multirow[t]{2}{*}{ Residence(\%) } & Urban & $2793(67.3 \%)$ & \multirow[t]{2}{*}{ Chronic disease(s)(\%) } & Yes & $580(14.0 \%)$ \\
\hline & Rural & $1355(32.7 \%)$ & & No & $3568(86.0 \%)$ \\
\hline
\end{tabular}


Attitudes and psychological impacts regarding COVID-19 and face masks

\begin{tabular}{|c|c|c|c|c|}
\hline \multicolumn{5}{|l|}{ The following are questions related to COVID-19 control } \\
\hline & & Yes & No & IDK \\
\hline 1.Do you think the COVID-19 pandemic will be successfully controlled? & & $2274(54.8)$ & $470(11.3)$ & 1404(33.8) \\
\hline 2.Do you think that you or one of your relatives will be infected with the COVID-19? & & $299(7.2)$ & 1502(36.2) & $2347(56.6)$ \\
\hline \multicolumn{5}{|l|}{ The following are questions related to COVID-19 attitudes and psychological impacts } \\
\hline & Not at all & A little bit & $\begin{array}{l}\text { To some } \\
\text { extent }\end{array}$ & A lot \\
\hline $\begin{array}{l}\text { 3. How well do you find yourself prepared to face the national spread of the COVID-19 } \\
\text { pandemic? }\end{array}$ & $388(9.4)$ & $1246(30.0)$ & $1369(33.0)$ & $1145(27.6)$ \\
\hline 4. Are you abiding to home quarantine rules? & $181(4.4)$ & 492(11.9) & $870(21.0)$ & 2605(62.8) \\
\hline 5. Is home quarantine causing an increase in family problems for you? & 1132(27.3) & $1100(26.5)$ & $1105(26.6)$ & $811(19.6)$ \\
\hline 6. Does home quarantine have a positive impact on your psychological state? & $1666(40.2)$ & $1007(24.3)$ & $836(20.2)$ & $639(15.4)$ \\
\hline 7. Is home quarantine causing you to feel lazy and inactive? & $678(16.3)$ & 737(17.8) & $1011(24.4)$ & 1722(41.5) \\
\hline \multicolumn{5}{|l|}{ The following are questions related to face mask attitudes, and psychological impacts } \\
\hline & & Yes & No & IDK \\
\hline 8. Do you support wearing a mask on the street? & & 2943(70.9) & $659(15.9)$ & $546(13.2)$ \\
\hline 9. Are you shy about wearing a mask in the street in front of people? & & $538(13.0)$ & $3275(79.0)$ & $335(8.1)$ \\
\hline 10. Do you have an inferior view of those who wear a mask and consider it a shame? & & $62(1.5)$ & $4010(96.7)$ & $76(1.8)$ \\
\hline 11. Do you worry about what people would say about you if you put on the mask? & & $584(14.1)$ & $3288(79.3)$ & $276(6.7)$ \\
\hline 12. Will you stop wearing a mask if you are embarrassed or bullied by people? & & $447(10.8)$ & $3237(78.0)$ & $464(11.2)$ \\
\hline
\end{tabular}


Table 3

Attitudes of participants by socio-demographic characteristics, $\mathrm{n}(\%)$

\begin{tabular}{|c|c|c|c|c|c|c|c|c|c|c|}
\hline & & \multicolumn{5}{|c|}{$\begin{array}{l}\text { 1. Do you think the COVID-19 pandemic will be successfully } \\
\text { controlled? }\end{array}$} & \multicolumn{4}{|c|}{$\begin{array}{l}\text { 2. Do you think that you or one of your relatives wil } \\
\text { with the COVID-19? }\end{array}$} \\
\hline & & Yes & No & IDK & $x^{2}$ & $\mathrm{P}$ & Yes & No & IDK & $x^{2}$ \\
\hline \multirow[t]{2}{*}{ Gender } & Male & $571(52.1 \%)$ & $193(17.6 \%)$ & $331(30.2 \%)$ & \multirow[t]{2}{*}{59.728} & \multirow{2}{*}{$\begin{array}{l}<.001 * \\
\end{array}$} & $126(11.5 \%)$ & $328(30.0 \%)$ & $641(58.5 \%)$ & \multirow[t]{2}{*}{55} \\
\hline & Female & $1703(55.8 \%)$ & $277(9.1 \%)$ & 1073(35.1\%) & & & $173(5.7 \%)$ & $1174(83.5 \%)$ & $1706(55.9 \%)$ & \\
\hline \multirow[t]{6}{*}{ Age group } & $<18$ & $81(50.9 \%)$ & $26(16.4 \%)$ & $52(32.7 \%)$ & \multirow[t]{6}{*}{38.487} & \multirow{6}{*}{ <. 001 * } & $15(9.4 \%)$ & $62(39.0 \%)$ & $82(51.6 \%)$ & \multirow[t]{6}{*}{23.} \\
\hline & $18-25$ & $1520(53.0 \%)$ & $339((11.8 \%)$ & $1011(35.2 \%)$ & & & $198(66.2 \%)$ & $994(34.6 \%)$ & $1678(58.5 \%)$ & \\
\hline & $26-34$ & $412(60.1 \%)$ & $57(10.9 \%)$ & 198(33.3\% & & & $59(8.6 \%)$ & $271(39.6 \%)$ & $355(51.8 \%)$ & \\
\hline & $35-44$ & $160(61.3 \%)$ & $14(5.4 \%)$ & $39(32.2 \%)$ & & & $19(7.3 \%)$ & $108(41.4 \%)$ & $134(51.3 \%)$ & \\
\hline & $45-54$ & $73(60.3 \%)$ & $9(7.4 \%)$ & $16(34.8 \%)$ & & & $4(3.3 \%)$ & $47(38.8 \%)$ & $70(57.9 \%)$ & \\
\hline & $55<$ & $26(56.5 \%)$ & $4(8.7 \%)$ & $1(16.7 \%)$ & & & $3(6.5 \%)$ & $16(34.8 \%)$ & $27(58.7 \%)$ & \\
\hline \multirow{3}{*}{$\begin{array}{l}\text { Social } \\
\text { status }\end{array}$} & Single & $1717(53.0 \%)$ & $403(12.4 \%)$ & $1118(34.5 \%)$ & \multirow[t]{3}{*}{31.721} & \multirow{3}{*}{$<.001 *$} & $230(7.1 \%)$ & $1141(35.2 \%)$ & $1867(57.7)$ & \multirow[t]{3}{*}{22.} \\
\hline & Married & $451(63.1 \%)$ & $48(6.7 \%)$ & $216(30.2)$ & & & $44(6.2 \%)$ & $301(42.1 \%)$ & $370(51.7 \%)$ & \\
\hline & Other & $106(54.4 \%)$ & 19(9.7\%) & $70(35.9 \%)$ & & & $25(12.8 \%)$ & $60(30.8 \%)$ & $110(56.4 \%)$ & \\
\hline \multirow[t]{2}{*}{ Areas } & Urban & $1515(54.2 \%)$ & $323(11.6 \%)$ & $955(34.2 \%)$ & \multirow[t]{2}{*}{1.236} & \multirow[t]{2}{*}{0.539} & $199(7.1 \%)$ & $983(35.2 \%)$ & $1611(57.7 \%)$ & \multirow[t]{2}{*}{4.3} \\
\hline & Rural & $759(56.0 \%)$ & $147(10.8 \%)$ & $449(33.1 \%)$ & & & $100(7.4 \%)$ & $519(38.3 \%)$ & $736(54.3 \%)$ & \\
\hline \multirow[t]{6}{*}{ Education } & Primary school & $25(86.2 \%)$ & $2(6.9 \%)$ & $2(6.9 \%)$ & \multirow[t]{6}{*}{50.003} & \multirow{6}{*}{$<.001 *$} & $3(10.3 \%)$ & $15(51.7 \%)$ & $11(37.9 \%)$ & \multirow[t]{6}{*}{22.6} \\
\hline & Secondary school & $92(56.4 \%)$ & $18(11.0 \%)$ & $53(32.5 \%)$ & & & $13(8.0 \%)$ & $65(39.9 \%)$ & $85(52.1 \%)$ & \\
\hline & High school & $279(59.9 \%)$ & $41(8.8 \%)$ & $146(31.3 \%)$ & & & $36(7.7 \%)$ & )$^{184(39.5 \%}$ & $264(52.8 \%)$ & \\
\hline & University/College & $1761(53.7 \%)$ & $377(11.5 \%)$ & $1140(34.8 \%)$ & & & $219(6.7 \%)$ & $1168(35.6 \%)$ & 1891(57.7\%) & \\
\hline & Master's degree & $106(57.3 \%)$ & $29(15.7 \%)$ & $50(27.0 \%)$ & & & $24(13.0 \%)$ & $63(34.1 \%)$ & $98(53.0 \%)$ & \\
\hline & PHD & $11(40.7 \%)$ & $3(0.1 \%)$ & $13(48.1 \%)$ & & & $4(14.8 \%) 11$ & $7(25.9 \%)$ & $16(59.3 \%)$ & \\
\hline \multirow[t]{7}{*}{ Occupation } & $\begin{array}{l}\text { Health care } \\
\text { worker }\end{array}$ & $151(57.6 \%)$ & $33(12.6 \%)$ & $78(29.8 \%)$ & \multirow[t]{7}{*}{53.775} & \multirow[t]{7}{*}{$<.001 *$} & $29(11.1 \%)$ & $89(34.0 \%)$ & $144(55.0 \%)$ & \multirow[t]{7}{*}{$40 . \varsigma$} \\
\hline & $\begin{array}{l}\text { Government } \\
\text { institution }\end{array}$ & $154(64.4 \%)$ & $16(6.7 \%)$ & $69(28.9 \%)$ & & & $13(5.4 \%)$ & $105(43.9 \%)$ & $121(50.6 \%)$ & \\
\hline & Private institution & $113(55.9 \%)$ & $33(16.3 \%)$ & $56(27.7 \%)$ & & & $22(10.9 \%)$ & $83(41.1 \%)$ & $97(48.0 \%)$ & \\
\hline & Business & $120(59.1 \%)$ & $29(14.3 \%)$ & $54(26.6 \%)$ & & & $21(10.3 \%)$ & $73(36.0 \%)$ & $109(53.7 \%)$ & \\
\hline & Military & $21(60.0 \%)$ & $3(8.6 \%)$ & $11(31.4 \%)$ & & & $3(8.6 \%)$ & $11(31.4 \%)$ & $21(60.0 \%)$ & \\
\hline & Student & $1307(51.5 \%)$ & $310(12.2 \%)$ & $923(36.3 \%)$ & & & $174(6.9 \%)$ & $862(33.9 \%)$ & $1504(59.2 \%)$ & \\
\hline & Other & $408(61.2 \%)$ & $46(6.9 \%)$ & $213(31.9 \%)$ & & & $37(5.5 \%)$ & $279(41.8 \%)$ & $351(52.6 \%)$ & \\
\hline \multirow{4}{*}{$\begin{array}{l}\text { Economical } \\
\text { status }\end{array}$} & Excellent & $152(56.9 \%)$ & $30(11.2 \%)$ & $85(31.8 \%)$ & 9.449 & 0.150 & $23(8.6 \%)$ & $113(42.3 \%)$ & $131(49.1 \%)$ & 16.4 \\
\hline & Good & $1027(54.5 \%)$ & $204(10.8 \%)$ & $654(34.7 \%)$ & & & $113(6.0 \%)$ & $683(36.2 \%)$ & $1089(57.8 \%)$ & \\
\hline & Moderate & $858(54.5 \%)$ & $173(11.0 \%)$ & $542(34.5 \%)$ & & & $121(7.7 \%)$ & $553(35.2 \%)$ & $899(57.2 \%)$ & \\
\hline & Poor & $237(56.0 \%)$ & $63(14.9 \%)$ & $123(29.1 \%)$ & & & $42(9.9 \%)$ & $153(36.2 \%)$ & $228(53.9 \%)$ & \\
\hline chronic & Yes & $315(54.3 \%)$ & $81(14.0 \%)$ & $184(31.7 \%)$ & 5.062 & 0.080 & $62(10.7 \%)$ & 195(33.6\%) & $323(55.7 \%)$ & $12 . t$ \\
\hline & No & $1959(54.9 \%)$ & $389(10.9 \%)$ & $1220(34.2 \%)$ & & & $237(6.6 \%)$ & $1307(31.5 \%)$ & $2024(56.7 \%)$ & \\
\hline
\end{tabular}


Table 4

Attitudes of participants by socio-demographic characteristics, $n(\%)$

\begin{tabular}{|c|c|c|c|c|c|c|c|c|c|c|}
\hline \multicolumn{2}{|c|}{ Characteristics } & \multicolumn{6}{|c|}{$\begin{array}{l}\text { 3. How well do you find yourself prepared to face the national spread of the } \\
\text { COVID-19 pandemic? }\end{array}$} & \multicolumn{3}{|c|}{ 4. Are you abiding to home quarantir } \\
\hline & & Not at all & A little bit & Sometimes & Too much & $x^{2}$ & $\mathrm{P}$ & Not at all & A little bit & Sometin \\
\hline \multirow[t]{2}{*}{ Gender } & Male & $94(8.6 \%)$ & $311(28.4 \%)$ & $344(31.4 \%)$ & $346(31.6 \%)$ & \multirow[t]{2}{*}{12.005} & \multirow[t]{2}{*}{$0.007 *$} & $102(9.3 \%)$ & $180(16.4 \%)$ & $274(25 \%$ \\
\hline & Female & $294(9.6 \%)$ & $935(30.6 \%)$ & $1025(33.6 \%)$ & $799(26.2 \%)$ & & & $79(1.9 \%)$ & $312(10.2 \%)$ & $596(19$. \\
\hline \multirow[t]{6}{*}{ Age group } & $<18$ & $18(11.3 \%)$ & $51(32.1 \%)$ & $50(3.7 \%)$ & $40(52.2 \%)$ & \multirow[t]{6}{*}{41.590} & \multirow[t]{6}{*}{$0.001^{*}$} & $4(2.5 \%)$ & $6(3.8 \%)$ & $42(26.4$ \\
\hline & $18-25$ & $270(9.4 \%)$ & $852(29.7 \%)$ & $1000(34.8 \%)$ & $748(26.1 \%)$ & & & $103(3.6 \%)$ & $330(11.5 \%)$ & $603(21 \%$ \\
\hline & $26-34$ & $64(9.3 \%)$ & $217(31.7 \%)$ & $202(29.5 \%)$ & $202(29.5 \%)$ & & & $41(6 \%)$ & $95(13.9 \%)$ & $135(19$. \\
\hline & $35-44$ & $26(10 \%)$ & $72(27.6 \%)$ & $72(27.6 \%)$ & $91(34.9 \%)$ & & & $17(6.5 \%)$ & $35(13.4 \%)$ & $52(19.9$ \\
\hline & $45-54$ & $8(6.6 \%)$ & $39(32.2 \%)$ & $35(28.9 \%)$ & $39(32.2 \%)$ & & & $11(9.1 \%)$ & $19(15.7 \%)$ & $28\left(23.1^{c}\right.$ \\
\hline & $55<$ & $0(0 \%)$ & $14(30.4 \%)$ & $10(21.7 \%)$ & $22(47.8 \%)$ & & & $2(4.3 \%)$ & $6(13 \%)$ & $10\left(21.7^{c}\right.$ \\
\hline \multirow{3}{*}{$\begin{array}{l}\text { Social } \\
\text { status }\end{array}$} & Single & $289(8.9 \%)$ & $973(30 \%)$ & $1123(34.7 \%)$ & $853(26.3 \%)$ & \multirow[t]{3}{*}{34.637} & \multirow{3}{*}{$\dot{0.001 *}$} & $121(3.7 \%)$ & $366(11.3 \%)$ & $667(20$ \\
\hline & Married & $69(9.7 \%)$ & $229(32 \%)$ & $193(27 \%)$ & $224(31.3 \%)$ & & & $46(6.4 \%)$ & $105(14.7 \%)$ & $157(22 \%$ \\
\hline & Other & $30(15.4 \%)$ & $44(22.6 \%)$ & $53(27.2 \%)$ & $68(34.9 \%)$ & & & $14(7.2 \%)$ & $21(10.8 \%)$ & $46\left(23.6^{c}\right.$ \\
\hline \multirow[t]{2}{*}{ Areas } & Urban & $258(9.2 \%)$ & $840(30.1 \%)$ & $909(32.5 \%)$ & $786(28.1 \%)$ & \multirow[t]{2}{*}{1.569} & \multirow[t]{2}{*}{0.666} & $102(3.7 \%)$ & $334(12 \%)$ & 593(21.2 \\
\hline & Rural & $130(9.6 \%)$ & $406(30 \%)$ & $460(33.9 \%)$ & $358(26.5 \%)$ & & & $79(5.8 \%)$ & $158(11.7 \%)$ & $277(20$ \\
\hline \multirow[t]{6}{*}{ Education } & Primary school & $4(13.8 \%)$ & $2(6.9 \%)$ & $12(41.4 \%)$ & $11(37.8 \%)$ & \multirow[t]{6}{*}{27.310} & \multirow[t]{6}{*}{$0.026^{*}$} & $4(13.8 \%)$ & $4(13.8 \%)$ & $5(17.2 \%$ \\
\hline & Secondary school & $23(14.1 \%)$ & $51(32.3 \%)$ & $44(27 \%)$ & $45(27.6 \%)$ & & & $19(11.7 \%)$ & $17(10.4 \%)$ & $35\left(21.5^{c}\right.$ \\
\hline & High school & $57(12.2 \%)$ & $134(28.8 \%)$ & $159(34.1 \%)$ & $116(24.9 \%)$ & & & $27(5.8 \%)$ & $45(9.7 \%)$ & 108(23.2 \\
\hline & University/College & $287(8.8 \%)$ & $1002(30.6 \%)$ & 1091(33.3\%) & $898(27.4 \%)$ & & & $121(3.7 \%)$ & $398(12.1 \%)$ & $669(20$. \\
\hline & Master's degree & $15(8.1 \%)$ & $50(27 \%)$ & $55(29.7 \%)$ & $65(35.1 \%)$ & & & $7(3.8 \%)$ & $24(13 \%)$ & $46\left(24.9^{c}\right.$ \\
\hline & PHD & $2(7.4 \%)$ & $7(25.9 \%)$ & $8(29.6 \%)$ & $10(37 \%)$ & & & $3(11.1 \%)$ & $4(14.8 \%)$ & $7(25.9 \%$ \\
\hline \multirow[t]{7}{*}{ Occupation } & $\begin{array}{l}\text { Health care } \\
\text { worker }\end{array}$ & $19(7.3 \%)$ & $58(22.1 \%)$ & $90(34.4 \%)$ & $95(36.3 \%)$ & \multirow[t]{7}{*}{50.003} & \multirow[t]{7}{*}{$<001$} & $22(8.4 \%)$ & $46(17.6 \%)$ & $62(23.7$ \\
\hline & $\begin{array}{l}\text { Government } \\
\text { institution }\end{array}$ & $20(8.4 \%)$ & $80(33.5 \%)$ & $54(22.6 \%)$ & $85(35.6 \%)$ & & & $11(4.6 \%)$ & $26(10.9 \%)$ & $44(18.4$ \\
\hline & Private institution & $14(6.9 \%)$ & $70(34.7 \%)$ & $61(30.2 \%)$ & $57(28.2 \%)$ & & & $14(6.9 \%)$ & $37(18.3 \%)$ & $40\left(19.8^{c}\right.$ \\
\hline & Business & $19(9.4 \%)$ & $53(26.1 \%)$ & 71(35.\%) & $60(29.6 \%)$ & & & $18(8.9 \%)$ & $43(21.2 \%)$ & $53\left(26.1^{c}\right.$ \\
\hline & Military & $3(8.6 \%)$ & $11(31.4 \%)$ & $11(31.4 \%)$ & $10(28.6 \%)$ & & & $9(25.7 \%)$ & $11(31.4 \%)$ & $6(17.1 \%$ \\
\hline & Student & $237(9.3 \%)$ & $776(30.6 \%)$ & $889(35 \%)$ & $638(25.1 \%)$ & & & $69(2.7 \%)$ & $242(9.5 \%)$ & $533(21 \%$ \\
\hline & Other & $76(11.4 \%)$ & $198(29.7 \%)$ & $193(28.9 \%)$ & $200(30 \%)$ & & & $38(5.7 \%)$ & $87(13 \%)$ & $132(19.8$ \\
\hline \multirow{4}{*}{$\begin{array}{l}\text { Economical } \\
\text { status }\end{array}$} & Excellent & $25(9.4 \%)$ & $61(22.8 \%)$ & $89(33.3 \%)$ & $92(34.5 \%)$ & \multirow[t]{4}{*}{46.689} & \multirow{4}{*}{$<.001^{*}$} & $16(6 \%)$ & $21(7.9 \%)$ & $65(24.3$ \\
\hline & Good & $142(7.5 \%)$ & $550(29.2 \%)$ & $674(35.8 \%)$ & $519(27.5 \%)$ & & & $54(2.9 \%)$ & $208(11 \%)$ & $395(21 \%$ \\
\hline & Moderate & $160(10.2 \%)$ & $512(32.5 \%)$ & $495(31.5 \%)$ & $406(25.8 \%)$ & & & $74(4.7 \%)$ & $205(13 \%)$ & $329(20$ \\
\hline & Poor & $61(14.4 \%)$ & $123(29.1 \%)$ & $111(26.2 \%)$ & $128(30.3 \%)$ & & & $37(8.7 \%)$ & $58(13.7 \%)$ & $81\left(19.1^{\circ}\right.$ \\
\hline \multirow{2}{*}{$\begin{array}{l}\text { chronic } \\
\text { diseases }\end{array}$} & Yes & $62(10.7 \%)$ & $167(13.4 \%)$ & $176(30.3 \%)$ & $175(30.2 \%)$ & \multirow[t]{2}{*}{4.691} & \multirow[t]{2}{*}{0.196} & $28(4.8 \%)$ & $75(12.9 \%)$ & $132(22 . \&$ \\
\hline & No & $326(9.1 \%)$ & $1079(30.2 \%)$ & 1193(33.4\%) & $970(27.2 \%)$ & & & $153(5.3 \%)$ & $417(11.7 \%)$ & $738(20$. \\
\hline
\end{tabular}


Attitudes of participants by socio-demographic characteristics

\begin{tabular}{|c|c|c|c|c|c|c|c|c|c|c|}
\hline \multicolumn{2}{|c|}{ Characteristics } & \multicolumn{6}{|c|}{ 5. Is home quarantine causing an increase in family problems for you? } & \multicolumn{3}{|c|}{ 6. Does home quarantine have a pos } \\
\hline & & Not at all & A little bit & Sometimes & Too much & $x^{2}$ & $\mathrm{P}$ & Not at all & A little bit & Som \\
\hline \multirow[t]{2}{*}{ Gender } & Male & $342(31.2 \%)$ & $270(24.7 \%)$ & $299(27.3 \%)$ & $184(16.8 \%)$ & \multirow[t]{2}{*}{16.412} & \multirow[t]{2}{*}{$0.001 *$} & $495(45.2 \%)$ & $235(21.5 \%)$ & 194 \\
\hline & Female & $790(19 \%)$ & $830(27.2 \%)$ & $806(26.4 \%)$ & $627(20.5 \%)$ & & & $1171(38.4 \%)$ & $772(25.3 \%)$ & 642 \\
\hline \multirow[t]{6}{*}{ Age group } & $<18$ & $32(20.1 \%)$ & $44(27.7 \%)$ & $44(27.7 \%)$ & $39(24.5 \%)$ & \multirow[t]{6}{*}{68.436} & \multirow{6}{*}{ <. $001 *$} & $65(40.9 \%)$ & $39(24.5 \%)$ & $33(2$ \\
\hline & $18-25$ & $728(25.4 \%)$ & $793(27.6 \%)$ & $747(26 \%)$ & $602(21 \%)$ & & & $1239(43.2 \%)$ & $716(24.9 \%)$ & 529 \\
\hline & $26-34$ & $214(31.2 \%)$ & $161(23.5 \%)$ & $192(28 \%)$ & $118(17.2 \%)$ & & & $257(37.5 \%)$ & $165(24.1 \%)$ & 150 \\
\hline & $35-44$ & $91(34.9 \%)$ & $68(26.1 \%)$ & $70(26.8 \%)$ & $32(13.3 \%)$ & & & $65(24.9 \%)$ & $49(18.8 \%)$ & $78(2$ \\
\hline & $45-54$ & $38(31.4 \%)$ & $29(24 \%)$ & $40(33.1 \%)$ & $39(32.2 \%)$ & & & $24(19.8 \%)$ & $28(23.1 \%)$ & $36(2$ \\
\hline & $55<$ & $25(54.3 \%)$ & $5(10.9 \%)$ & $12(26.1 \%($ & $4(8.7 \%)$ & & & $12(26.1 \%)$ & $10(21.7 \%)$ & $8(17$ \\
\hline \multirow{3}{*}{$\begin{array}{l}\text { Social } \\
\text { status }\end{array}$} & Single & $289(8.8 \%)$ & $973(30 \%)$ & $1123(34.7 \%)$ & $853(26.3 \%)$ & \multirow[t]{3}{*}{22.253} & \multirow[t]{3}{*}{$0.001 *$} & $1353(41.8 \%)$ & $813(25.1 \%)$ & 613 \\
\hline & Married & $69(9.7 \%)$ & $229(32 \%)$ & 193(27\%) & $224(31.3 \%)$ & & & 225(31.5\%) & $154(21.5 \%)$ & 188 \\
\hline & Other & $30(15.4 \%)$ & $44(22.6 \%)$ & $53(27.2 \%)$ & $68(34.9 \%)$ & & & $88(45.1 \%)$ & $1007(24.3 \%)$ & 836 \\
\hline \multirow[t]{2}{*}{ Areas } & Urban & $750(26.9 \%)$ & $734(26.3 \%)$ & $754(27 \%)$ & $555(19.9 \%)$ & \multirow[t]{2}{*}{1.638} & \multirow[t]{2}{*}{0.651} & 1114(39.9\%) & $650(23.3 \%)$ & 584 \\
\hline & Rural & $382(28.2 \%)$ & $366(27 \%)$ & $351(25.9 \%)$ & $256(18.9 \%)$ & & & $552(40.7 \%)$ & $357(26.3 \%)$ & 252 \\
\hline \multirow[t]{6}{*}{ Education } & Primary school & $4(13.8 \%)$ & $2(6.9 \%)$ & $12(41.4 \%)$ & $11(37.9 \%)$ & \multirow[t]{6}{*}{35,606} & \multirow[t]{6}{*}{$0.002^{*}$} & $10(34.5 \%)$ & $7(24.1 \%)$ & $4(13$ \\
\hline & Secondary school & $23(14.1 \%)$ & $51(31.3 \%)$ & $44(27 \%)$ & $45(27.6 \%)$ & & & $59(36.2 \%)$ & $43(26.4 \%)$ & $35(2$ \\
\hline & High school & $57(12.2 \%)$ & $134(28.8 \%)$ & 159(34.1\%) & $116(24.9 \%)$ & & & 186(39.9\%) & $120(25.8 \%)$ & $88(1$ \\
\hline & University/College & $287(8.8 \%)$ & $1002(30.6 \%)$ & 1091(33.3\%) & $898(27.4 \%)$ & & & $1336(40.8 \%)$ & $798(24.3 \%)$ & 665 \\
\hline & Master's degree & $15(8.1 \%)$ & $50(27 \%)$ & $55(29.7 \%)$ & $65(35.1 \%)$ & & & $64(34.6 \%)$ & $37(20 \%)$ & $38(2$ \\
\hline & PHD & $2(7.4 \%)$ & $7(25.9 \%)$ & $8(29.6 \%)$ & $10(37 \%)$ & & & $11(40.7 \%)$ & $2(7.4 \%)$ & $6(22$ \\
\hline \multirow[t]{7}{*}{ Occupation } & $\begin{array}{l}\text { Health care } \\
\text { worker }\end{array}$ & $88(33.6 \%)$ & $64(24.4 \%)$ & $76(29 \%)$ & $34(13 \%)$ & \multirow[t]{7}{*}{50.572} & \multirow[t]{7}{*}{$\hat{0.001 *}$} & $85(32.4 \%)$ & $54(20.6 \%)$ & $57(2$ \\
\hline & $\begin{array}{l}\text { Government } \\
\text { institution }\end{array}$ & $92(38.5 \%)$ & $59(24.7 \%)$ & $49(20.5 \%)$ & $39(16.3 \%)$ & & & $64(26.8 \%)$ & $46(19.2 \%)$ & $65(2$ \\
\hline & Private institution & $60(29.7 \%)$ & $51(25.2 \%)$ & $58(28.7 \%)$ & $33(16.3 \%)$ & & & $64(31.7 \%)$ & $50(24.8 \%)$ & $52(2$ \\
\hline & Business & $64(31.5 \%)$ & $43(21.2 \%)$ & $55(27.1 \%)$ & $41(20.2 \%)$ & & & $96(47.3 \%)$ & $47(23.2 \%)$ & $33(1$ \\
\hline & Military & $10(28.6 \%)$ & $12(34.3 \%)$ & $10(28.6 \%)$ & $3(8.6 \%)$ & & & $15(42.9 \%)$ & $8(22.9 \%)$ & $7(20$ \\
\hline & Student & $624(24.6 \%)$ & $703(27.7 \%)$ & $670(26.4 \%)$ & $543(21.4 \%)$ & & & $1092(43 \%)$ & $637(25.1 \%)$ & 476 \\
\hline & Other & $194(29.1 \%)$ & $168(25.2 \%)$ & $187(28 \%)$ & $118(17.7 \%)$ & & & $250(37.5 \%)$ & $165(24.7 \%)$ & 146 \\
\hline \multirow{4}{*}{$\begin{array}{l}\text { Economical } \\
\text { status }\end{array}$} & Excellent & $102(38.2 \%)$ & $64(24 \%)$ & $60(22.5 \%)$ & $41(15.4 \%)$ & \multirow[t]{4}{*}{50.267} & \multirow{4}{*}{ <. $001 *$} & $85(31.8 \%)$ & $69(25.8 \%)$ & $49(1$ \\
\hline & Good & $523(27.7 \%)$ & $536(28.4 \%)$ & $503(26.7 \%)$ & $323(17.1 \%)$ & & & $731(38.8 \%)$ & $469(24.9 \%)$ & 405 \\
\hline & Moderate & $407(25.9 \%)$ & $398(25.3 \%)$ & $441(28 \%)$ & $327(20.8)$ & & & $653(41.5 \%)$ & $376(23.9 \%)$ & 318 \\
\hline & Poor & $100(23.6 \%)$ & $102(24.1 \%)$ & $101(23.9 \%)$ & $120(28.4 \%)$ & & & 197(46.6\%) & $93(22 \%)$ & $64(1$ \\
\hline \multirow{2}{*}{$\begin{array}{l}\text { chronic } \\
\text { diseases }\end{array}$} & Yes & $152(26.2 \%)$ & $136(23.4 \%)$ & $142(24.5 \%)$ & $150(25.9 \%)$ & \multirow[t]{2}{*}{17.598} & \multirow[t]{2}{*}{$0.001^{*}$} & $267(46 \%)$ & $123(21.2 \%)$ & $98(1$ \\
\hline & No & $980(27.5 \%)$ & $964(27 \%)$ & $963(27 \%)$ & $661(18.5 \%)$ & & & $1399(39.2 \%)$ & $884(24.8 \%)$ & 738 \\
\hline
\end{tabular}


Table 6

Attitudes of participants by socio-demographic characteristics, $\mathrm{n}(\%)$

\begin{tabular}{|c|c|c|c|c|c|c|c|c|c|c|}
\hline & & \multicolumn{6}{|c|}{ 7. Is home quarantine causing you to feel lazy and inactive? } & \multicolumn{3}{|c|}{ 8. Do you support wearing a mask a } \\
\hline & & Not at all & A little bit & Sometimes & Too much & $x^{2}$ & $\mathrm{P}$ & Yes & No & IDK \\
\hline \multirow[t]{2}{*}{ Gender } & Male & $212(19.4 \%)$ & $186(17 \%)$ & $281(25.7 \%)$ & $416(38 \%)$ & \multirow[t]{2}{*}{14.250} & \multirow[t]{2}{*}{$0.003^{*}$} & $\begin{array}{l}758 \\
(69.2 \%)\end{array}$ & $\begin{array}{l}213 \\
(19.5 \%)\end{array}$ & $124(1$ \\
\hline & Female & $466(15.3 \%)$ & $551(18 \%)$ & $730(23.9 \%)$ & $1306(42.8 \%)$ & & & $\begin{array}{l}2185 \\
(71.6 \%)\end{array}$ & $\begin{array}{l}446 \\
(14.6 \%)\end{array}$ & $\begin{array}{l}422 \\
(13.8 \mathrm{c}\end{array}$ \\
\hline \multirow[t]{6}{*}{ Age group } & $<18$ & $30(18.9 \%)$ & $22(13.8 \%)$ & $38(23.9 \%)$ & $69(43.4 \%)$ & \multirow[t]{6}{*}{233.290} & \multirow{6}{*}{ <. $001 *$} & $113(71.1 \&)$ & $16(10.1 \%)$ & $30(18$ \\
\hline & $18-25$ & $354(12.3 \%)$ & $498(17.4 \%)$ & $655(22.8 \%)$ & $1363(47.5 \%)$ & & & $\begin{array}{l}2073 \\
(72.2 \%)\end{array}$ & $400(13.9)$ & $\begin{array}{l}397 \\
(13.8 \mathrm{c}\end{array}$ \\
\hline & $26-34$ & $155(22.6 \%)$ & $142(20.7 \%)$ & $193(28.2 \%)$ & $195(28.5 \%)$ & & & $479(69.9 \%)$ & 130(19.0\&) & $76(11$ \\
\hline & $35-44$ & $76((29.1 \%)$ & $45(17.2 \%)$ & $77(29.5 \%)$ & $63(24.2 \%)$ & & & $169(64.8 \%)$ & $65(24.9 \%)$ & $27(10$ \\
\hline & $45-54$ & $43 ; 35.5 \%)$ & $24(19.8 \%)$ & $31(25.6 \%)$ & 23(19\%) & & & $75(62.0 \%)$ & $35(28.9 \%)$ & $11(9.1$ \\
\hline & $55<$ & $16(34.8 \%)$ & $6(13 \%)$ & $17(37 \%)$ & $7(15.2 \%)$ & & & $32(69.6 \%)$ & $11(23.9 \%)$ & $3\left(6.5^{c}\right.$ \\
\hline \multirow[t]{3}{*}{$\begin{array}{l}\text { Social } \\
\text { status }\end{array}$} & Single & $455(14.1 \%)$ & $567(17.5 \%)$ & $743(22.9 \%)$ & $1473(45.5 \%)$ & \multirow[t]{3}{*}{133.430} & \multirow[t]{3}{*}{ <. $001 *$} & $\begin{array}{l}2316 \\
(71.5 \%)\end{array}$ & $477(14.7 \%)$ & $445(1$ \\
\hline & Married & $183(25.6 \%)$ & $138(19.3 \%)$ & $223(31.2 \%)$ & $171(23.9 \%)$ & & & $493(69.0 \%)$ & $147(20.6 \%)$ & $75(10$ \\
\hline & Other & $40(20.5 \%)$ & $32(16.4 \%)$ & $45(23.2 \%)$ & $78(40 \%)$ & & & $134(68.7 \%)$ & $35(17.9 \%)$ & $26(13$ \\
\hline \multirow[t]{2}{*}{ Areas } & Urban & $436(15.6 \%)$ & $491(17.6 \%)$ & $690(24.7 \%)$ & $1176(68.3 \%)$ & \multirow[t]{2}{*}{4.099} & \multirow[t]{2}{*}{0.251} & 1957(70.1\%) & $461(16.5 \%)$ & $375(1$ \\
\hline & Rural & $242(17.9 \%)$ & $246(18.2 \%)$ & $321(23.7 \%)$ & $546(40.3 \%)$ & & & $986(72.8 \%)$ & $198(14.6 \%)$ & $171(1$ \\
\hline \multirow[t]{6}{*}{ Education } & Primary school & $11(37.9 \%)$ & $2(6.9 \%)$ & $9(31 \%)$ & $7(24.1 \%)$ & \multirow[t]{6}{*}{81.834} & \multirow{6}{*}{$\stackrel{<}{0.001 *}$} & $19(65.5 \%)$ & $6(20.7 \%)$ & 4(13.\& \\
\hline & Secondary school & $42(25.8 \%)$ & $17(10.4 \%)$ & $50(30.7 \%)$ & $54(33.1 \%)$ & & & $116(71.2 \%)$ & $27(16.6 \%)$ & $20(12$ \\
\hline & High school & $92(19.7 \%)$ & $93(20 \%)$ & $103(22.1 \%)$ & $178(38.2 \%)$ & & & $326(70.0 \%)$ & $77(16.5 \%)$ & $63(13$ \\
\hline & University/College & $477(14.6 \%)$ & $583(17.8 \%)$ & $786(24 \%)$ & $1432(43.7 \%)$ & & & $2344(71.5 \%)$ & $498(15.2 \%)$ & $436(1$ \\
\hline & Master's degree & $49(25.9 \%)$ & $37(20 \%)$ & $53(28.6 \%)$ & $46(24.9 \%)$ & & & $125(67.6 \%)$ & $41(22.2 \%)$ & $19(10$ \\
\hline & PHD & $7(25.9 \%)$ & $5(18.5 \%)$ & $10(37 \%)$ & $5(18.5 \%)$ & & & $13(48.1 \%)$ & $10(37.0 \%)$ & $4(14 . \varepsilon$ \\
\hline \multirow[t]{7}{*}{ Occupation } & $\begin{array}{l}\text { Health care } \\
\text { worker }\end{array}$ & $64(24.4 \%)$ & $43(16.4 \%)$ & $82(31.3 \%)$ & $73(27.9 \%)$ & \multirow[t]{7}{*}{190.180} & \multirow[t]{7}{*}{$\hat{0}_{0.001 *}$} & $179(68.3 \%)$ & $62(23.7 \%)$ & $21(8 . c$ \\
\hline & $\begin{array}{l}\text { Government } \\
\text { institution }\end{array}$ & $66(27.6 \%)$ & $51(21.3 \%)$ & $63(26.4 \%)$ & $59(24.7 \%)$ & & & 170(71.1) & $44(18.4 \%)$ & $25(10$ \\
\hline & Private institution & $46(22.8 \%)$ & $45(22.3 \%)$ & $46(22.8 \%)$ & $65(32.2 \%)$ & & & $138(68.3 \%)$ & $50(24.8 \%)$ & $14(6$. ؟ \\
\hline & Business & $51(25.1 \%)$ & $29(14.3 \%)$ & $52(25.6 \%)$ & $71(35 \%)$ & & & 125(61.6) & $47(23.2 \%)$ & $31(15$ \\
\hline & Military & $12(34.3 \%)$ & $8(22.9 \%)$ & $9(25.7 \%)$ & $6(17.1 \%)$ & & & $23(65.7 \%)$ & $8(22.9 \%)$ & $4(11.4$ \\
\hline & Student & $301(11.9 \%)$ & $424(16.7 \%)$ & $585(23 \%)$ & $1239(48.4 \%)$ & & & $1834(72.2 \%)$ & $341(13.4 \%)$ & $365(1$ \\
\hline & Other & $138(20.7 \%)$ & $137(20.5 \%)$ & $174(26.1 \%)$ & $218(32.7 \%)$ & & & $474(71.1 \%)$ & $107(16.0 \%)$ & $86(12$ \\
\hline \multirow{4}{*}{$\begin{array}{l}\text { Economical } \\
\text { status }\end{array}$} & Excellent & $41(15.4 \%)$ & $40(15 \%)$ & $78(29.2 \%)$ & $108(40.4 \%)$ & \multirow[t]{4}{*}{13.205} & \multirow[t]{4}{*}{0.154} & 195(73.0\%) & $43(16.1 \%)$ & $29(10$ \\
\hline & Good & $290(15.4 \%)$ & $358(19 \%)$ & $444(23.6 \%)$ & $793(42.1 \%)$ & & & $1367(72.5 \%)$ & $284(15.1 \%)$ & $234(1$ \\
\hline & Moderate & $278(17.7 \%)$ & $262(16.7 \%)$ & $398(25.3 \%)$ & $635(40.4 \%)$ & & & 1102(70.1\%) & $244(15.5 \%)$ & $227(1$ \\
\hline & Poor & $69(16.3 \%)$ & $77(18.2 \%)$ & $91(21.5 \%)$ & $186(44 \%)$ & & & $279(66.0 \%)$ & $88(20.8 \%)$ & $56(13$ \\
\hline \multirow{2}{*}{$\begin{array}{l}\text { chronic } \\
\text { diseases }\end{array}$} & Yes & $101(17.4 \%)$ & $93(16 \%)$ & $140(24.1 \%)$ & $246(42.2 \%)$ & \multirow[t]{2}{*}{1.758} & \multirow[t]{2}{*}{0.624} & $411(70.9 \%)$ & $90(15.5 \%)$ & $79(13$ \\
\hline & No & $577(16.2 \%)$ & $644(18 \%)$ & $871(24.4 \%)$ & $1476(41.4 \%)$ & & & $2532(71.0 \%)$ & $569(15.9 \%)$ & $467(1$ \\
\hline
\end{tabular}


Table 7

Attitudes of participants by socio-demographic characteristics, $\mathrm{n}(\%)$

\begin{tabular}{|c|c|c|c|c|c|c|c|c|c|c|c|}
\hline & & \multicolumn{5}{|c|}{$\begin{array}{l}\text { 9. Are you shy about wearing a mask and/or gloves in the } \\
\text { street in front of people? }\end{array}$} & \multicolumn{5}{|c|}{$\begin{array}{l}\text { 10. Do you have an inferior view of those who wear a } \\
\text { mask and/or gloves and consider it a shame? }\end{array}$} \\
\hline & & Yes & No & IDK & $x^{2}$ & $\mathrm{P}$ & Yes & No & IDK & $x^{2}$ & $\mathrm{P}$ \\
\hline \multirow[t]{2}{*}{ Gender } & Male & $\begin{array}{l}153 \\
(14.0 \%)\end{array}$ & $882(80.5 \%)$ & $60(5.5 \%)$ & \multirow[t]{2}{*}{14.053} & \multirow[t]{2}{*}{$0.001 *$} & $26(2.4 \%)$ & $1034(94.4 \%)$ & $35(3.2 \%)$ & \multirow[t]{2}{*}{23.588} & \multirow[t]{2}{*}{$\begin{array}{l}< \\
0.0\end{array}$} \\
\hline & Female & $385(12.6 \%)$ & $\begin{array}{l}2393 \\
(78.4 \%)\end{array}$ & $275(9.0 \%)$ & & & $36(1.2 \%)$ & $2976(97.5 \%)$ & $41(1.3 \%)$ & & \\
\hline \multirow[t]{6}{*}{ Age group } & $<18$ & $25(15.7 \%)$ & 121(76.1\%) & $13(8.2 \%)$ & \multirow[t]{6}{*}{30.833} & \multirow[t]{6}{*}{$0.002^{*}$} & $4(2.5 \%)$ & 145(91.2\%) & $10(6.3 \%)$ & \multirow[t]{6}{*}{38.201} & \multirow{6}{*}{$\begin{array}{l}< \\
0.0\end{array}$} \\
\hline & $18-25$ & $384(13.4 \%)$ & $2229(77.7 \%)$ & $257(9.0 \%)$ & & & $43(1.5 \%)$ & $2775(96.7 \%)$ & $52(1.8 \%)$ & & \\
\hline & $26-34$ & $85(12.4 \%)$ & $565(82.5 \%)$ & $35(5.1 \%)$ & & & $6(0.9 \%)$ & $671(98.0 \%)$ & $8(1.2 \%)$ & & \\
\hline & $35-44$ & $31(11.9 \%)$ & $212(81.2 \%)$ & $18(6.9 \%)$ & & & $3(1.1 \%)$ & 256(98.1\%) & $2(0.8 \%)$ & & \\
\hline & $45-54$ & $8(6.6 \%)$ & $106(87.6 \%)$ & $7(5.8 \%)$ & & & $4(3.3 \%)$ & $115(95.0 \%)$ & $2(1.7 \%)$ & & \\
\hline & $55<$ & $2(4.3 \%)$ & $39(84.8 \%)$ & $5(10.9 \%)$ & & & $1(2.2 \%)$ & $43(93.5 \%)$ & $2(4.3 \%)$ & & \\
\hline \multirow[t]{3}{*}{$\begin{array}{l}\text { Social } \\
\text { status }\end{array}$} & Single & $438(13.5 \%)$ & $\begin{array}{l}2522 \\
(77.9 \%)\end{array}$ & $278(8.6 \%)$ & \multirow[t]{3}{*}{11.701} & \multirow[t]{3}{*}{$0.020^{*}$} & $45(1.4 \%)$ & $3131(96.7 \%)$ & $62(1.9 \%)$ & \multirow[t]{3}{*}{$5.489 a$} & \multirow[t]{3}{*}{0.2} \\
\hline & Married & $80(11.2 \%)$ & $594(83.1 \%)$ & $41(5.7 \%)$ & & & $11(1.5 \%)$ & $691(96.6 \%)$ & $13(1.8 \%)$ & & \\
\hline & Other & $20(10.3 \%)$ & $159(81.5 \%)$ & $16(8.2 \%)$ & & & $6(3.1 \%)$ & 188(96.4\%) & $1(0.5 \%)$ & & \\
\hline \multirow[t]{2}{*}{ Areas } & Urban & $354(12.7 \%)$ & $\begin{array}{l}2218 \\
(79.4 \%)\end{array}$ & $221(7.9 \%)$ & \multirow[t]{2}{*}{1.087} & \multirow[t]{2}{*}{0.581} & $41(1.5 \%)$ & $2699(96.6 \%)$ & $53(1.9 \%)$ & \multirow[t]{2}{*}{0.242} & \multirow[t]{2}{*}{0.8} \\
\hline & Rural & $184(13.6 \%)$ & $\begin{array}{l}1057 \\
(78.0 \%)\end{array}$ & $114(8.4 \%)$ & & & $21(1.5 \%)$ & $1311(96.8 \%)$ & $23(1.7 \%)$ & & \\
\hline \multirow[t]{6}{*}{ Education } & Primary school & $6(20.7 \%)$ & $22(75.9 \%)$ & $1(3.4 \%)$ & \multirow[t]{6}{*}{17.538} & \multirow[t]{6}{*}{0.063} & $2(6.9 \%)$ & $27(93.1 \%)$ & $0(0.0 \%)$ & \multirow[t]{6}{*}{29.435} & 0.0 \\
\hline & Secondary school & $24(14.7 \%)$ & $131(80.4 \%)$ & $8(4.9 \%)$ & & & $6(3.7 \%)$ & $149(91.4 \%)$ & $8(4.9 \%)$ & & \\
\hline & High school & $59(12.7 \%)$ & $363(77.9 \%)$ & $44(9.4 \%)$ & & & $11(2.4 \%)$ & $442(94.8 \%)$ & $13(2.8 \%)$ & & \\
\hline & University/College & $431(13.1 \%)$ & $2574(78.5 \%)$ & $273(8.3 \%)$ & & & $42(1.3 \%)$ & $3184(97.1 \%)$ & $52(1.6 \%)$ & & \\
\hline & Master's degree & $17(9.2 \%)$ & $162(87.6 \%)$ & $6(3.2 \%)$ & & & $1(0.5 \%)$ & $181(97.8 \%)$ & $3(1.6 \%)$ & & \\
\hline & PHD & $1(3.7 \%)$ & $23(85.2 \%)$ & $3(11.1)$ & & & $0(0.0 \%)$ & $27(100.0 \%)$ & $0(0.0 \%)$ & & \\
\hline Occupation & $\begin{array}{l}\text { Health care } \\
\text { worker }\end{array}$ & $20(7.6 \%)$ & $227(86.6 \%)$ & $15(5.7 \%)$ & 45.024 & $<.001 *$ & $3(1.1 \%)$ & $252(96.2 \%)$ & $7(2.7 \%)$ & 12.684 & 0.3 \\
\hline & $\begin{array}{l}\text { Government } \\
\text { institution }\end{array}$ & $32(13.4 \%)$ & $190(79.5 \%)$ & $17(7.1 \%)$ & & & $2(0.8 \%)$ & 233(97.5\%) & $4(1.7 \%)$ & & \\
\hline & Private institution & $17(8.4 \%)$ & $175(86.6 \%)$ & $10(5.0 \%)$ & & & $3(1.5 \%)$ & 196(97.0\%) & $3(1.5 \%)$ & & \\
\hline & Business & $36(17.7 \%)$ & $161(79.3 \%)$ & $6(3.0 \%)$ & & & $7(3.4 \%)$ & 194(95.6\%) & $2(1.0 \%)$ & & \\
\hline & Military & $1(2.9 \%)$ & $31(88.6 \%)$ & $3(8.6 \%)$ & & & $1(2.9 \%)$ & $34(97.1 \%)$ & $0(0.0 \%)$ & & \\
\hline & Student & $356(14.0 \%)$ & $1943(76.5 \%)$ & $241(9.5 \%)$ & & & $35(1.4 \%)$ & $2452(96.5 \%)$ & $53(2.1 \%)$ & & \\
\hline & Other & $76(11.4 \%)$ & $548(82.2 \%)$ & $43(6.4 \%)$ & & & $11(1.6 \%)$ & 649(97.3\%) & $7(1.0 \%)$ & & \\
\hline Economical & Excellent & $31(11.6 \%)$ & $224(83.9 \%)$ & $12(4.5 \%)$ & 12.810 & $0.046^{*}$ & $5(1.9 \%)$ & $257(96.3 \%)$ & $5(1.9 \%)$ & 10.254 & 0.1 \\
\hline & Good & $223(11.8 \%)$ & $1494(79.3 \%)$ & $168(8.9 \%)$ & & & $20(1.1 \%)$ & $1837(97.5 \%)$ & $28(1.5 \%)$ & & \\
\hline & Moderate & $218(13.9 \%)$ & $1233(78.4 \%)$ & $122(7.8 \%)$ & & & $32(2.0 \%)$ & 1504(95.6\%) & $37(2.4 \%)$ & & \\
\hline & Poor & $66(15.6 \%)$ & $324(76.6 \%)$ & $33(7.8 \%)$ & & & $5(1.2 \%)$ & $412(97.4 \%)$ & $6(1.4 \%)$ & & \\
\hline $\begin{array}{l}\text { chronic } \\
\text { diseases }\end{array}$ & Yes & $63(10.9 \%)$ & $478(82.4 \%)$ & $39(6.7 \%)$ & 4.859 & 0.088 & $13(2.2 \%)$ & $557(96.0 \%)$ & $10(1.7 \%)$ & 2.587 & 0.2 \\
\hline & No & $475(13.3 \%)$ & $2797(78.4 \%)$ & $296(8.3 \%)$ & & & $49(1.4 \%)$ & $3453(96.8 \%)$ & $66(1.8 \%)$ & & \\
\hline
\end{tabular}


Table 8

Attitudes of participants by socio-demographic characteristics, $\mathrm{n}(\%)$

\begin{tabular}{|c|c|c|c|c|c|c|c|c|c|c|}
\hline & & \multicolumn{5}{|c|}{$\begin{array}{l}\text { 11. Do you worry about what people would say about you if } \\
\text { you put on the mask and/or gloves? }\end{array}$} & \multicolumn{4}{|c|}{$\begin{array}{l}\text { 12. Will you stop wearing a mask and/or gloves if you } \\
\text { embarrassed or bullied by people? }\end{array}$} \\
\hline & & Yes & No & IDK & $x^{2}$ & $\mathrm{P}$ & Yes & No & IDK & $x^{2}$ \\
\hline \multirow[t]{2}{*}{ Gender } & Male & $177(16.2 \%)$ & 848(77.4\%) & $70(6.4 \%)$ & \multirow[t]{2}{*}{5.372} & \multirow[t]{2}{*}{0.068} & $144(13.2 \%)$ & $842(76.9 \%)$ & $109(10.0 \%)$ & \multirow[t]{2}{*}{10.050} \\
\hline & Female & $407(13.3 \%)$ & $2440(79.9 \%)$ & $206(6.7 \%)$ & & & $303(9.9 \%)$ & 2395(78.4\%) & $355(11.6 \%)$ & \\
\hline \multirow[t]{6}{*}{ Age group } & $<18$ & $22(13.8 \%)$ & $121(76.1 \%)$ & $16(10.1 \%)$ & \multirow[t]{6}{*}{69.578} & \multirow{6}{*}{ <. $001 *$} & $24(15.1 \%)$ & 111(69.8\%) & $24(15.1 \%)$ & \multirow[t]{6}{*}{46.509} \\
\hline & $18-25$ & $459(16.0 \%)$ & $2203(76.8 \%)$ & $208(7.2 \%)$ & & & $327(11.4 \%)$ & 2192(76.4\%) & $351(12.2 \%)$ & \\
\hline & $26-34$ & 77(11.2\%) & $568(82.9 \%)$ & $40(5.8 \%)$ & & & 69(10.1\%) & $551(80.4 \%)$ & $65(9.5 \%)$ & \\
\hline & $35-44$ & $18(6.9 \%)$ & 237(90.8\%) & $6(2.3 \%)$ & & & $16(6.1 \%)$ & $230(88.1 \%)$ & $15(5.7 \%)$ & \\
\hline & $45-54$ & $5(4.1 \%)$ & $112(92.6 \%)$ & $4(3.3 \%)$ & & & $7(5.8 \%)$ & 108(89.3\%) & $6(5.0 \%)$ & \\
\hline & $55<$ & $0(0.0 \%)$ & $44(95.7 \%)$ & $2(4.3 \%)$ & & & $4(7.7 \%)$ & $45(86.5 \%)$ & $3(5.8 \%)$ & \\
\hline \multirow{3}{*}{$\begin{array}{l}\text { Social } \\
\text { status }\end{array}$} & Single & $500(15.4 \%)$ & $2508(77.5 \%)$ & $230(7.1 \%)$ & \multirow[t]{3}{*}{32.203} & \multirow{3}{*}{$<.001 *$} & $374(11.6 \%)$ & 2477(76.5\%) & $387(12.0 \%)$ & \multirow[t]{3}{*}{21.761} \\
\hline & Married & $60(8.4 \%)$ & 617(86.3\%) & $38(5.3 \%)$ & & & $54(7.6 \%)$ & 603(84.3\%) & $58(8.1 \%)$ & \\
\hline & Other & $24(12.3 \%)$ & 163(83.6\%) & $8(4.1 \%)$ & & & $19(9.7 \%)$ & 157(80.5\%) & $19(9.7 \%)$ & \\
\hline \multirow[t]{2}{*}{ Areas } & Urban & $377(13.5 \%)$ & 2242(80.3\%) & $174(6.2 \%)$ & \multirow[t]{2}{*}{5.449} & \multirow[t]{2}{*}{0.066} & $286(10.2 \%)$ & $2209(79.1 \%)$ & $298(10.7 \%)$ & \multirow[t]{2}{*}{5.537} \\
\hline & Rural & $207(15.3 \%)$ & $1046(77.2 \%)$ & $102(7.5 \%)$ & & & $161(11.9 \%)$ & $1028(75.9 \%)$ & $166(12.3 \%)$ & \\
\hline \multirow[t]{6}{*}{ Education } & Primary school & $6(20.7 \%)$ & $20(69.0 \%)$ & $3(10.3 \%)$ & \multirow[t]{6}{*}{22.409} & \multirow[t]{6}{*}{$0.013^{*}$} & $5(17.2 \%)$ & $23(79.3 \%)$ & $1(3.4 \%)$ & \multirow[t]{6}{*}{14.937} \\
\hline & Secondary school & $21(12.9 \%)$ & $127(77.9 \%)$ & $15(9.2 \%)$ & & & $22(13.5 \%)$ & 127(77.9\%) & $14(8.6 \%)$ & \\
\hline & High school & $51(10.9 \%)$ & 393(84.3\%) & $22(4.7 \%)$ & & & $49(10.5 \%)$ & $371(79.6 \%)$ & $46(9.9 \%)$ & \\
\hline & University/College & $484(14.8 \%)$ & 2567(78.3\%) & $227(6.9 \%)$ & & & $350(10.7 \%)$ & $2540(77.5 \%)$ & $388(11.8 \%)$ & \\
\hline & Master's degree & $22(11.9 \%$ & 157(84.9\%) & $6(3.2 \%)$ & & & $21(11.4 \%)$ & $150(81.1 \%)$ & $14(7.6 \%)$ & \\
\hline & PHD & $0(0.0 \%)$ & $24(88.9 \%)$ & $3(11.1 \%)$ & & & $0(0.0 \%)$ & $26(96.3 \%)$ & $1(3.7 \%)$ & \\
\hline \multirow[t]{7}{*}{ Occupation } & $\begin{array}{l}\text { Health care } \\
\text { worker }\end{array}$ & $20(7.6 \%)$ & $228(87.0 \%)$ & $14(5.3 \%)$ & \multirow[t]{7}{*}{47.722} & \multirow[t]{7}{*}{$<.001 *$} & $27(10.3 \%)$ & $213(81.3 \%)$ & $22(8.4 \%)$ & \multirow[t]{7}{*}{29.857} \\
\hline & $\begin{array}{l}\text { Government } \\
\text { institution }\end{array}$ & $24(10.0 \%)$ & $204(85.4 \%)$ & $11(4.6 \%)$ & & & $19(7.9 \%)$ & 197(82.4\%) & $23(9.6 \%)$ & \\
\hline & Private institution & $29(14.4 \%)$ & $160(79.2 \%)$ & $13(6.4 \%)$ & & & $16(7.9 \%)$ & $167(82.7 \%)$ & $19(9.4 \%)$ & \\
\hline & Business & $24(11.8 \%)$ & 173(85.2\%) & $6(3.0 \%)$ & & & $26(12.8 \%)$ & 163(80.3\%) & $14(6.9 \%)$ & \\
\hline & Military & $4(11.4 \%)$ & $30(85.7 \%)$ & $1(2.9 \%)$ & & & $6(17.1 \%)$ & $29(82.9 \%)$ & $0(0.0 \%)$ & \\
\hline & Student & $416(16.4 \%)$ & 1934(76.1\%) & $190(7.5 \%)$ & & & $293(11.5 \%)$ & 1925(75.8\%) & $322(12.7 \%)$ & \\
\hline & Other & $67(10.0 \%)$ & $559(83.8 \%)$ & $41(6.1 \%)$ & & & $60(9.0 \%)$ & $543(81.4 \%)$ & $64(9.6 \%)$ & \\
\hline \multirow{4}{*}{$\begin{array}{l}\text { Economical } \\
\text { status }\end{array}$} & Excellent & $32(12.0 \%)$ & $220(82.4 \%)$ & $15(5.6 \%)$ & 12.511 & 0.051 & $25(9.4 \%)$ & 208(77.9\%) & $34(12.7 \%)$ & 17.475 \\
\hline & Good & $242(15.6 \%)$ & 1497(79.4\%) & $146(7.7 \%)$ & & & $169(9.0 \%)$ & 1507(79.9\%) & $209(11.1 \%)$ & \\
\hline & Moderate & $245(15.6 \%)$ & 1237(78.6\%) & $91(5.8 \%)$ & & & $202(12.8 \%)$ & 1189(75.6\%) & $182(11.6 \%)$ & \\
\hline & Poor & $65(15.4 \%)$ & $334(79.0 \%)$ & $24(5.7 \%)$ & & & $51(12.1 \%)$ & $333(78.7 \%)$ & $39(9.2 \%)$ & \\
\hline chronic & Yes & $70(12.1 \%)$ & $476(82.1 \%)$ & $34(5.9 \%)$ & 3.238 & 0.198 & $61(10.5 \%)$ & $468(80.7 \%)$ & $51(8.8 \%)$ & 4.102 \\
\hline & No & $514(14.4 \%)$ & $2812(78.8 \%)$ & $242(6.8 \%)$ & & & $386(10.8 \%)$ & $2769(77.6 \%)$ & $413(11.6 \%)$ & \\
\hline
\end{tabular}

\section{Supplementary Files}

This is a list of supplementary files associated with this preprint. Click to download.

- Appendix.docx 